\title{
LAS COFRADÍAS DE LA VERA CRUZ EN EL RENNO DE NAVARRA (SIGLOS XVI-XVIII) ${ }^{1}$
}

\author{
POR
}

\author{
GREgorio SILANES SUSAETA*
}

\section{RESUMEN}

Las primeras cofradías de la Vera Cruz se fundan en el reino de Navarra en la segunda mitad del siglo XVI, en aplicación de las disposiciones del Concilio de Trento. En estas páginas se describe su forma de organización y los principales cometidos que realiza.

\section{ABSTRACT}

The first confraternities of the Vera Cruz are established in the Kingdom of Navarra in second half of the XVIth century, in application of the arrangements of the Council of Trento. In these pages is described their form of organization and the principal assignments that accomplishes.

\section{INTRODUCCIÓN}

La Semana Santa tal y como la conocemos hoy comenzó a forjarse en España desde finales de la Edad Media ${ }^{2}$. Las principales artffices de la organización

\footnotetext{
* Dr. en Historia por la Universidad Pública de Navarra.

1 Siglas principales:

ADP Archivo Diocesano de Pamplona.

AMP: Archivo Municipal de Pamplona.

AHN: Archivo Histórico Nacional.

2 J. SÁNCHEz HerRero, «Las cofradías de Semana Santa de Sevilla durante la modernidad. Siglos XV a XVII", en R. SÁNCHEZ MANTERo et al., Las cofradías de Sevilla en la modernidad, Sevilla, 1991, pp. 50-52.
}

Actas del I Congreso de Historia de la Iglesia y el Mundo Hispánico Hispania Sacra, 52 (2000) 
de las procesiones fueron las cofradías, especialmente las de la Vera Cruz, existentes en infinidad de localidades. Una nota característica de estas cofradías en toda la geografia española, y por supuesto en la navarra, es la práctica pública de la disciplina. Una de las primeras cofradías de la Vera Cruz está documentada en Sevilla al menos desde $1448^{3}$. En Navarra tenemos que esperar al siglo XVI para encontrar menciones de este tipo de cofradías. La primera que se ha encontrado es la de Sangüesa, de la que se tienen noticias en 1541. De la cofradía de Pamplona se habla en las actas de un proceso judicial litigado en el Real Consejo de Navarra hacia el año 1563. Según se desprende de ellas la cofradía de la Vera Cruz de Pamplona ya existía en 1552 fundada en el Monasterio del Carmen, y a ella legó en su testamento el soldado Hernando de Oviedo una casa que poseía en el barrio de la Magdalena ${ }^{4}$. La de Genevilla ya existía para 1551, la de Cascante ${ }^{5}$ se fundó en 1560 , las constituciones de la de Lerín ${ }^{6}$ están fechadas en 1565 y las de Olite en 1567.

Los orígenes más antiguos.de las cofradias de disciplinantes, por extensión en la Navarra moderna las de la Vera Cruz, están en la predicación y doctrina de San Francisco de Asís que difundió entre los laicos la actitud de penitencia voluntaria. Para finales del siglo XIII el movimiento se extendió desde Italia por buena parte de Europa, especialmente a partir de la predicación de Raniero Fasani en la ciudad de Perusa hacia 1260. Fasani proponía la disciplina pública espectacular, de modo que en algunas ciudades italianas se llegó a perder el verdadero sentido primigenio de la actitud penitencial emanada de la espiritualidad de san Francisco, llegándose a entablar verdaderas competiciones, a lo largo de la Baja Edad Media, sobre quién se disciplinaba más y mejor. Por otro lado el trágico siglo XIV (jalonado por la Guerra de los Cien Años y la Peste Negra en sus años centrales) vio un cambio en la mentalidad colectiva, dando origen a una angustia que se manifestó en un culto mayor a la Pasión de Cristo ${ }^{8}$.

Fueron en realidad los franciscanos quienes durante el siglo $\mathrm{XV}$, por lo menos durante la segunda mitad, promovieron las cofradias de disciplinantes en España con el nombre de la Vera Cruz'. En las constituciones de las cofradías, establecidas con frecuencia en los conventos de franciscanos allá donde exis-

\footnotetext{
${ }^{3}$ J. MESEguer FernÁNDEZ, "Las cofradías de la Vera Cruz», en Archivo Iberoamericano, 109-110, 1968, p. 203.

${ }^{4}$ M. NúNEzZ de CePEDA, Gremios y cofradias de Pamplona, Pamplona, 1947, p. 292.

5 J.I. Fernández Marco, S. J., Cascante: sus iglesias, sus cofradlas y devociones, Bilbao, 1996, p. 127.

6 ADP, $\mathrm{C} / .9 \mathrm{n}^{\circ} 17$.

$7 \mathrm{ADP}, \mathrm{C} / .1538 \mathrm{n}^{\circ} 9$

I J. SÁnCHeZ HeRrero, Las cofradias de Semana Santa.., pp. 29-38.

${ }^{9}$ Ibid, p. 43.
}

Actas del I Congreso de Historia de la Iglesia y el Mundo Hispánico Hispania Sacra, 52 (2000) 
tían, se suele manifestar claramente esta influencia espiritual, como sucede en las constituciones de la cofradía establecida en la iglesia parroquial de Armañanzas en 1582, cuyos hermanos toman «...por capitán y guía de esta hermandad» a Jesucristo, y «(...) por alférez y abogado de nuestra batalla al glorioso san Francisco, a quien dio Cristo nuestro capitán la bandera de su milicia» ${ }^{10}$. También los cofrades de Villafranca toman «(...) por alférez y aduogado desta hermandad al gloriosso señor san Francisco, a quien Cristo Nuestro Señor, Dios e rredemptor dio la bandera de su clemencia, imprimiendo en su sagrado cuerpo exteriormente las armas e insignias de su sagrada passion y victoria (...) $) 11$.

Todas las cofradías de la Vera Cruz tenían en común un triple carácter, el penitencial, el indulgencial y el pasionario; es decir que al menos en sus inicios practicaron la disciplina pública, que mediante ello y otro tipo de prácticas religiosas ganaban una serie de indulgencias, y que todas participaban y organizaban las procesiones de Semana Santa ${ }^{12}$.

\section{Orígenes de las cofradias de la Vera Cruz en Navarra}

A pesar de que en Castilla algunas cofradías llevaban ya más de cien años funcionando, el momento cuando comienzan a establecerse en el Reino de Navarra hay que retrasarlo por lo menos hasta mediados del siglo XVI, en que comenzarán a extenderse de forma masiva por todo el reino. El acicate para ello lo constituye un vivae vocis oraculo del Papa Paulo III, dado en 1536, a petición de los cofrades de Toledo. Estos, inquietos por las objecciones que más de un siglo antes había impuesto Jean Gerson a la disciplina pública como consecuencia de los excesos que se cometían, puesto que los disciplinantes no iban cubiertos como convenía a la decencia pública, solicitaron del cardenal franciscano español Francisco de Quiñones, que pidiera al Papa indulgencias para su cofradía. Con la carta de contestación el cardenal envió también por escrito el vivae vocis oraculo del Papa, en que concedía indulgencias no sólo a la cofradía toledana sino a todas las de la Vera Cruz ${ }^{13}$.

A partir de este momento es cuando empiezan a proliferar cofradias de la Vera Cruz. La cofradía de Villafranca, con constituciones de 1575, comenzó a existir, al igual que otras, como consecuencia de los privilegios concedidos por

I0 M. R. LAmela Nobajas, Armañanzas, en la colección Navarra: Temas de Cultura Popular, n. 298 , p. 14.

ADP, Cl. $63 \mathrm{n}^{\circ} 10$.

12 J. MESEguER FERnÁndeZ, op. cit., p. 202.

13 Ibid., pp. 204-207; J. SÁNCHEZ HERRERO, Las cofradias de Semana Santa.., pp. 60-61. 
Pablo III ${ }^{14}$. El Papa concedió en 1536 a todos los cofrades de la Vera Cruz, hombres como mujeres, que participaran en la procesión del jueves de la cena, o la acompañaran con sus candelas encendidas, estando contritos y confesados o con el propósito de confesar, todas las gracias e indulgencias que por los papas pasados fueron concedidas a los que visitaren personalmente el día de Viernes Santo las iglesias de Roma, o lo que es lo mismo indulgencia plenaria. También les concedía por participar en la procesión de Jueves Santo la facultad de elegir confesor, con plena potestad de absolver, aún incluso muchos de los pecados reservados, excepto los contenidos en el documento ${ }^{15}$. Asímismo podían ser absueltos de cualquier censura o entredicho promulgado por cualquier juez apostólico, y de cualquier voto que se hubiere realizado, excepto de los consejos evangélicos o de peregrinar a Roma, Jerusalén o Santiago ${ }^{16}$.

Los motivos para fundar las cofradías de la Vera Cruz son siempre los mismos, de acuerdo con las ideas expresadas en la Sesión VI de 13 de mayo de 1547 del Concilio de Trento donde se trató sobre la justificación. El concilio, frente a la concepción protestante sobre el tema de que es inútil hacer penitencia ni ninguna buena obra para merecer ante Dios, afirma la libertad del hombre que, iluminado por el Espíritu Santo que puede mover el corazón humano, es capaz de realizar libremente obras meritorias y penitencia para su justificación. No sólo eso sino que además exhorta a hacer penitencia por las penas temporales debidas por los pecados propios y por los ajenos ${ }^{17}$. Este es un segundo jalón en el surgimiento de las cofradías de la Vera Cruz en Navarra : la disposición favorable del concilio tridentino. Enseguida nacerán cofradías con estos motivos penitenciales a lo largo de todo el reino, fundadas, allí donde existía, en un convento de franciscanos generalmente, como es el caso de Tafalla, Olite, Estella o Pamplona desde mediados del siglo XVI, por citar los más representativos, o en multitud de parroquias de los núcleos rurales.

Las constituciones, semejantes en la mayoría de los casos, hacen saber en el preámbulo estos motivos de fundación, como rezan las de Armañanzas:

\footnotetext{
$14 \mathrm{ADP}, \mathrm{Cl} .63 \mathrm{n} .^{\circ} 10$.

Is Los cofrades de la Vera Cruz podían ser absueltos de "homicidios causales y mentales, de las transgresiones y quebrantamiento de los mandamientos de la yglesia, de la determinación boluntaria de poner, o de hecho aver puesto manos violentas en alguna persona o personas eclesiásticas, pero no si fueren obispos u otros prelados, de qualquiera regularidad mental o causal y todos los demás qualesquier pecados, crimenes, eccesos, delitos por muy graves y enormes que sean, aunque fuesen tales que por ellos y para la absolución dellos ubiese de ser consultada la santa sede apostólica, eceptos los casos de la bula de la cena y bigamos (...)m.

${ }^{16} \mathrm{ADP}, \mathrm{C} / .63, \mathrm{n}^{\circ} 10$, sin fol.

17 El Concilio de Trento en el Decreto sobre la justificación, emanado de la sesión sexta, no sólo recomienda el que se haga penitencia sino que, con palabras del propio Jesucristo (cfr. Mt 3,2; 3,8 y 4,17), exhorta a hacer penitencia (E. DENZINGER, El Magisterio de la Iglesia, Barcelona, 1959, p. 235).
}

Actas del I Congreso de Historia de la Iglesia y el Mundo Hispánico Hispania Sacra, 52 (2000) 


\begin{abstract}
«Alumbrados por la doctrina cristiana de la Santa Madre Iglesia Católica, tenemos por fe y firmemente creemos y confesamos inclinadas a misericordia las entrafias de nuestro Padre celestial, a los llantos de nuestros padres primeros por cuyo pecado fuimos hechos hijos de perdición, queriendo tomar carne humana para nuestra redención, envió al mundo a su unigénito hijo Nuestro Señor Jesucristo, el cual nos dio en hermano y amigo en su encarnación y en fin para nos reconciliar con el Padre y hacemos hijos de gracia, ofreció su cuerpo preciosísimo en sacrifico en ara de la Cruz, y derramó su preciosísima sangre en nuestro precio para que, redimidos de la miserable servidumbre, fuésemos limpiados de todos nuestros pecados para que el temor de la muerte de la cual por el pecado de nuestros primeros padres éramos dignos, convirtiésemos en esperanza de la vida eterna, a nosotros prometida; queriendo pues en memoria de tan gran beneficio e caridad mostrar alguna sefial de hijos gratos para en alguna satisfación y parte de recompensa de tanto bien y para alguna satisfacción de nuestras culpas y pecados, y para persuadir a los fieles cristianos a la memoria de su pasión, y al dolor y penitencia de sus culpas y pecados, ordenamos y establecemos esta hermandad y cofradia de la santa Vera Cruz (...) $){ }^{18}$.
\end{abstract}

\title{
3. Aceptación de las cofradias de la Vera Cruz
}

Las cofradías de la Vera Cruz en el Reino de Navarra eran cofradías generales devocionales, en las que solían participar buena parte de los habitantes de un determinado pueblo, ciudad o valle, o la totalidad de los habitantes. Por ejemplo en Estella, en 1771, eran cofrades de la Vera Cruz todos los habitantes de la ciudad $^{19}$, y lo mismo sucedía en Caparroso. En Milagro pasaban a formar parte de ella desde que eran bautizados. Sin embargo, en contadas ocasiones, no era así, por ejemplo la cofradía de Falces tan sólo está formada por gentes disinguidas de la villa, aquéllos que podían ser insaculados en la bolsa de alcalde de hidalgos ${ }^{20}$. Normalmente solían pertenecer a ellas hombres y mujeres, si bien estas no tenían voto en las juntas y tampoco podían salir como disciplinantes ni alumbrando las procesiones de Jueves Santo, tal y como rezan las constituciones de la de Villafranca ${ }^{21}$. Aun con todo, las cofradesas gozaban de los mismos beneficios espirituales que los hombres ${ }^{22}$. También tomaban parte de las cargas económicas de las cofradías al igual que los hombres, como se colige de las cuentas de la cofradía de Torres del Río el año 1694, donde se responsabiliza a

18 Cit. en M. R. LAMEla Nobajas, op. cit., p. 14. El mismo preámbulo se observa en las constituciones de la cofradía de Villafranca (cf. ADP, Cl. $63 \mathrm{n} .^{\circ} 10$, sin fol.), y en otras constituciones de cofradías de la Vera Cruz.

${ }^{19} \mathrm{AHN}$, Consejos, leg. 7096, fol. 244r.

20 ADP, Cl. 1847 n. 6 , fol. $1 \mathrm{r}$.

21 ADP, C/. 63 n. 10.

22 Un buen exponente de ello lo tenemos en la cofradía de la Vera Cruz de Cascante, donde se mencionan seis mujeres entre los difuntos de un afio, una de ellas dofa Maria Garcez de Urtubia, monja bernarda en Tulebras (Cfr. J. I. FERNÁNDEZ MARco SJ, Cascante: sus iglesias, sus cofradias y devociones, Bilbao, 1996, p. 129). 
los cargos de la cofradía de veinticinco reales y medio de plata del «... repartimiento a los hermanos confrades y confradessas en dicho año ${ }^{23}$.

Esta composición de las cofradías por gentes de toda condición dio lugar a tensiones en el seno de las mismas, que se solventaban, si era posible, en el seno de la cofradía. Si las tensiones llegaban a ser insalvables, entonces salían al exterior para ser dirimidas en los tribunales correspondientes: bien la Real Corte Mayor y el Real Consejo de Navarra, o los tribunales eclesiásticos. Puede servir como ejemplo lo que sucedió en la de Arguedas en 1671, formada por gentes de los dos estamentos de la villa: el hidalgo y el labrador. Según parece era costumbre que el pendón de la cofradía fuera llevado en las procesiones por los hidalgos del pueblo. Sin embargo en la procesión de Jueves Santo de ese año el prior encomendó esta tarea a un tal García Pérez, del estado de los francos o labradores. Se produjeron una serie de alborotos en la misma iglesia del pueblo antes de salir la procesión, con insultos y peleas entre los hermanos, de manera que la procesión tuvo que ser suspendida. Habiendo llegado noticia de estos desórdenes al cura de almas y fiscal eclesiástico, éste intervino con su autoridad, $y$, para evitar en la próxima procesión de la Cruz de mayo los desórdenes producidos el día de Jueves santo, nombró él mismo para llevar el pendón a Juan López de Torrecilla, del estamento de los francos ${ }^{24}$.

Los hidalgos se quejan porque ellos siempre han llevado el pendón, según costumbre. Sin embargo los francos ven la cosa de otra manera, pues alegan que, para llevar el pendón, únicamente es requisito ser cofrade y esto puede ser ordenado por el prior a cualquier miembro de la cofradía. El juez eclesiástico emite una sentencia salomónica: que el pendón sea llevado un año por los labradores y dos consecutivos por los hidalgos.

En ocasiones las cofradías de la Vera Cruz agrupaban a población de todo un valle o una cendea. Esto sucedía por ejemplo en el caso de Cizur, en que la cofradía se reunía en la basílica de Ardoi. También se observaba esto en la de Elorz, fundada en 1622, formada por personas de once lugares: Elorz, Zulueta, Zabalegui, Torres, Noain, Imarcoain, Óriz, Ezperun, Otano, Yárnoz y Andiquiáin ${ }^{25}$. En la localidad de Egüés asimismo había una cofradia de la que formaba parte todo el valle ${ }^{26}$, y lo mismo se estilaba en Esteríbar, cuya cofradía radicaba en Larrasoaña. El prior de ella iba a recoger limosna por todos los pueblos del valle $e^{27}$.

\footnotetext{
${ }^{23}$ ADP, Archivos Parroquiales, caj. 238, n. $^{\circ} 3$, Libro de cuentas de la Cofradía de la Vera Cruz de Torres del Río que comienza en 1690 y termina en 1765 , fol. 11 r.

${ }^{24}$ ADP, C/. 1095, n. ${ }^{\circ}$.

25 ADP, C $/ .650, \mathrm{n}^{\circ} 3$.

${ }^{26}$ AHN, Consejos, leg. 7096, fol. 232r.

${ }^{27}$ AHN, Consejos, leg. 7096, fol. 220v-221r.
}

Actas del 1 Congreso de Historia de la Iglesia y el Mundo Hispánico

Hispania Sacra, 52 (2000) 
Los patronos de las cofradías son, en numerosas ocasiones, los regimientos de las villas y ciudades, asociados a veces con los cabildos parroquiales. En la propia ciudad de Pamplona la cofradía de la Vera Cruz «(...) es una de las dos cofradías públicas que ay en esta ciudad fundadas por el Regimiento della, su único patrono, y su fundación se encaminó únicamente a beneficio de la causa pública (...) $\rangle^{28}$. La de Olite está fundada por el Regimiento y el cabildo del municipio, y el día de jueves santo, cuando organizaba la procesión, congregaba a todos los habitantes de la ciudad y se juntaban todos los hermanos de la cofradía, el cabildo de la parroquia y el Regimiento, en el convento de los franciscanos para escuchar el sermón que antecedía a la salida de la procesión ${ }^{29}$. En Olite el prior de la cofradía es siempre el alcalde de la ciudad, los mayordomos primeros eran elegidos por insaculación de la bolsa de alcaldes y los segundos de la bolsa de regidores ${ }^{30}$. En Pamplona el cargo de prior de la Vera Cruz siempre recaía en un regidor. En Lumbier los priores eran el cura y el alcalde ${ }^{31}$. También en Tafalla el Regimiento era el patrono de la cofradía ${ }^{32}$. En Miranda de Arga el municipio nombraba los cargos dirigentes ${ }^{33}$, y en Viana era patrona de la cofradía la ciudad, que elegía todos los afíos al prior ${ }^{34}$. Por su parte los regidores de la Cendea de Cizur asistían al nombramiento anual de capellán y ermitaño de la cofradía de la Vera Cruz, pese a las quejas de ésta, contra la que se querellan en 1749 ante el tribunal diocesano, porque los cofrades no quieren seguir cumpliendo esa tradición ${ }^{35}$.

Junto con el muncipio, el párroco, como agente de pastoral, tenía también su importancia a la hora de que se estableciese una cofradía de la Vera Cruz, por los beneficios espirituales que ello conllevaba en la población de acuerdo con las más ortodoxas formulaciones del Concilio de Trento. Así, al fundar una institución de este tipo, se concedia a la feligresía la posibilidad de ganar las indulgencias anexas que llevaban estas cofradías, la del ejercicio saludable de la penitencia y la de llevar una práctica sacramental y litứrgica en comunidad. Este papel del vicario parroquial se observa claramente en la fundación en 1572 de la cofradía de la Vera Cruz de Artajona ${ }^{36}$.

\footnotetext{
28 AMP, Cofradias y Hermandades, leg. 1, sin fol.

29 ADP, C/. 1538, n. $^{\circ}$.

30 Ibid.

31 AHN, Consejos, leg. 7096, fol. 168v.

32 AHN, Consejos, leg. 7096, fol. 130r.

33 AHN, Consejos, leg. 7096, fol. 131v.

${ }^{34}$ AHN, Consejos, leg. 7096, fol. 278v.

35 ADP, C/. 1618, n." 25.

$36 \mathrm{ADP}, \mathrm{Cl} .667, \mathrm{n}^{\circ}$ 22. Martín de las Heras, testigo presentado en las actas de este proceso, de 79 afios de edad, vecino de Artajona, dice que la licencia del obispo D. Diego Ramirez Sedeño de Fuenle-

Actas del I Congreso de Historia de la Iglesia y el Mundo Hispánico Hisparia Sacra, 52 (2000)
} 
Hacia 1770 había en el Reino de Navarra 129 cofradías de la Vera Cruz sobre un total de 1166 , lo que supone el $11,88 \%$. Esta cifra está muy lejos del casi $30 \%$ que representan las cofradías del Rosario, sobre el conjunto de las existentes. Eran muy profusas en la Merindad de Estella, de las que casi se contaba una en cada pueblo. Por el contrario, en ese momento, apenas las encontramos en la Merindad de Pamplona, al Norte de la capital, tan sólo en Leiza y Villava ${ }^{37}$.

En muchos casos se pretendía que estas cofradías constituyeran unas sociedades ejemplares de vida cristiana. Las constituciones de la cofradía de Villafranca prescriben «(...) que los que hubieren de ser rrecibidos en esta santa confraria sean cathólicos e fieles e no personas que los que se obiere de tractar en ellas lo tengan en menosprecio (...) $)^{38}$. El modo de ingresar en ella era mediante votación en el capítulo general que se tenía todos los años el 3 de mayo. Aunque normalmente se solía admitir a las mujeres como partícipes de los bienes espirituales e indulgencias de estas cofradías, si asistían a la procesión del jueves santo sin embargo, no les estaba permitido ir entre los disciplinantes. Por supuesto las mujeres tampoco tenían voto ni eran admitidas en las colaciones ${ }^{39}$.

\section{VIDA de las cofradtas navarras de la Vera CRUz}

Las actividades que desempanaban estas instituciones presentan una triple tipología: cultuales o religiosas, caritativas y sociales.

\section{a) Actividades cultuales o religiosas}

\section{La confesión sacramental}

Puede decirse que las cofradías de la Vera Cruz colaboraban sin duda con los «agentes de pastoral» (obispos, párrocos, órdenes religiosas) en cuanto a la creación del modelo de cristiano que la jerarquía postridentina proponía. El Concilio de Trento concedió capital importancia a la práctica sacramental y litúrgica de los fieles, sobre todo mediante la confesión y la eucaristía. Entre

\footnotetext{
al para fundar la cofradía «(...) la alcançó el licenciado don Juan de Sarasa, difunto, bicario que fue de la yglesia partochial del sefior san Cernin...y que, después que la obtubo, hizo juntar a las personas principales y honrradas de la dicha villa y les dio quenta della (...) y les dixo que los que querian entrar y ser confrades, él los asentaría y aría libro de las reglas y hordenanças que se haúan de guardar, y que anssí entraron muchos por cofrades, y los asentó, como consta del libro que dello ay (...)».

${ }^{37}$ Estos datos se obtienen del recuento de las cofradías de Navarra realizado a instancias del Conde de Aranda en 1771 (cfr. AHN, Consejos, leg. 7096).

${ }^{38} \mathrm{ADP}, \mathrm{C} / \mathrm{63}, \mathrm{n.}{ }^{\mathrm{p}} 10$, sin fol.

${ }^{39}$ Ibid.
}

Actas del 1 Congreso de Historia de la Iglesia y el Mundo Hispánico

Hispania Sacra, 52 (2000) 
otras cosas se dispuso en Trento que por lo menos todos los fieles cristianos confesaran y comulgaran al menos una vez al año, lo que se dispuso se hiciera en torno a la Pascua de Resurrección. En este sentido todas las constituciones de las cofradías de la Vera Cruz recogen en su texto el precepto de confesar en torno al día de Jueves Santo. De ese modo se ganarían además las indulgencias que estas cofradías tenían concedidas por asistir a la procesión de Jueves Santo $^{40}$. Los cofrades de Sansol debían confesar además para la Cruz de setiembre y para Navidad.

\section{Las procesiones de Semana Santa}

Ya hemos apuntado al principio que las cofradias de la Vera Cruz eran las encargadas de organizar en pueblos y ciudades las procesiones de Semana Santa, sobre todo la del Jueves Santo.

Para salir en la procesión, los hermanos se juntaban en un lugar determinado, que, en el caso de Villafranca era la iglesia, donde, después de haber tomado una colación más o menos frugal y escuchado el sermón de mandato, se. vestían la túnica blanca, que solía ser de hilo, con una capucha para ocultar el rostro, y con posibilidad de abrirse por la espalda. En algunos pueblos, como en Lerín o Villafranca, la túnica llevaba un escudo de las Cinco Llagas en la parte del pecho. También poseía cada hermano un cordón de esparto o cáñamo (que los cofrades de la Vera Cruz de Sansol llaman todavía hoy el lío), y unas disciplinas. Luego salían todos en procesión, en primer lugar los sacerdotes, detrás de ellos un cofrade con una cruz, a la distancia máxima posible de los demás de modo que pueda verse la imagen del crucificado, y luego los demás cofrades, uno detrás de otro, 0 de dos en dos, con las espaldas descubiertas quienes se fueren a disciplinar. Al terminar la procesión, volviendo de nuevo al lugar de partida, la iglesia parroquial normalmente, los cofrades que tenían intención comenzaban a flagelarse, hincándose de rodillas al canto $O$ crux aue spes unica. Luego salian de la iglesia por orden y en silencio hasta que los que se habian disciplinado eran lavados y curados ${ }^{41}$. Para la cura de sus heridas se empleaba en Artajona "vino escalentado" ${ }^{42}$. Para llevar un orden en la procesión, de veinte en veinte cofrades debía ir un crucifijo. La disciplina no era lo

40 Las constituciones de la cofradía de Elorz rezan que para ir en la procesión de Jueves Santo, «(...) todos los cofrades, antes de salir de ella, se junten en un lugar diputado para este efecto, precediendo ante y primero la confesión (...) (ADP, C/.650, n..3).

41 Así se procedía en Villafranca en torno a 1575 (ADP, C/. 63, n. 10 ).

42 ADP, C/.667, n. 22. 
más importante, puesto que los que no se podían flagelar habían de llevar insignias de la Pasión. La cofradía de Olite la dejaba a devoción de los fieles, que sustituirían este inconveniente con una limosna ${ }^{43}$. Los mayordomos y otras personas que ellos ordenaren, irían apartando a la gente para que no se mezclase con los penitentes, con unos escudos en los que estaban representadas las Cinco Llagas. Junto con los cofrades que se disciplinaban, llamados de sangre o de disciplina, iban los de luz, que, con sus hachones de cera encendidos, iluminaban a aquéllos.

Esta procesión, según la fuente utilizada, parece muy simple, pues únicamente se lleva una cruz a la cabeza de la misma. En muchas de las parroquias de la Merindad de Estella queda, como imagen original de la cofradía algún crucificado romanista (como los de Sansol) o barroco. Con el paso del tiempo las procesiones de Semana Santa de la Vera Cruz fueron adquiriendo novedades. Según nuestros conocimientos, a pesar de que hoy en día ya no hay disciplinantes, las procesiones sin embargo se han ido barroquizando con el tiempo, añadiendo nuevos pasos como el Cristo alzado, la Virgen Soledad o Dolorosa, una cruz hueca de grandes dimensiones, para llevar a cuestas, cargándola un cofrade como si fuera Jesús, acompañado en la parte delantera por un «sayón»» que lo lleva atado, $y$ en la parte trasera por uno que hace de cirineo ${ }^{44}$, y una gran cadena para llevar arrastrando, enroscada por el cuerpo. Esto se puede ver todavía en el día de hoy, por ejemplo, en la procesión de Viemes Santo de Sansol, en la que además los cofrades, siguiendo la tradición de sus mayores, van descalzos, vestidos con su túnica blanca de hilo y la cabeza cubierta con una capucha. También se hacía de esta forma, o de manera parecida, en otras localidades de la Merindad de Estella. No obstante la jerarquía procuraba, en la medida de lo posible, controlar abusos que se producían en este sentido, allí donde se habían introducido rasgos exagerados de teatralidad barroca. Algo de esto sucedió en la procesión de Jueves Santo que se celebraba en Elorz organizada por la cofradía del valle. En ella iba un cofrade que, a imitación de Cristo, llevaba una túnica y cabellos largos ensangrentados, cubierta la cabeza con una corona de espinas, descalzo, «(...) con passos muy grabes y espaciossos (...)», con una cruz a cuestas. El cura de almas de la diócesis queja contra esta cofradía, considerando un abuso lo que hacen, y les prohíbe en 1622 que lleven la túnica ensangrentada ${ }^{45}$.

\footnotetext{
43 ADP, C/. 1538, n. $^{\circ} 9$.

44 De todas formas esta representación de Jesús en la Vía Dolorosa parece que se haría desde los primeros tiempos de las cofradías. Las constituciones de la cofradía de Artajona, redactadas en 1572 dicen: «Item, después de la cruz parroquial, uno de los cofrades, bestido con un túnica ençangrentada con unos cabellos largos y una diadema, a de llebar una cruz tan grande quanto sus fuerças con pena la pueda llebar, en figura de la cruz que fue muy grande, y a de ir descalço el confrade que la llebare» (ADP, C/.667, n. ${ }^{\circ} 22$ ).

${ }^{45} \mathrm{ADP}, \mathrm{Cl} / 650, \mathrm{n} .3$.
}

Actas del I Congreso de Historia de la Iglesia y el Mundo Hispánico

Hispania Sacra, 52 (2000) 
El pueblo gustaba de las procesiones de Semana Santa, especialmente de la flagelación en público de los hermanos cofrades. Esto lo atestigua el P. Calatayud, que se sirve del «espectáculo» que causa la disciplina masiva en público para atraer a la gente a sus misiones ${ }^{46}$. De todas formas no cabe duda de que se produjeron abusos en la práctica de la penitencia. En 1769 se publica una Real Cédula de Carlos III donde se prohíbe disciplinarse públicamente junto con otras manifestaciones externas de la piedad popular ${ }^{47}$. También los obispos toman cartas en el asunto, y así, el 28 de marzo de 1770, el obispo pamplonés D. Juan Lorenzo de Irigoyen y Dutari publicó un edicto pastoral contra esta práctica porque los penitentes marchaban «(...) sin más vestidura que unos simples calzoncillos, quedando por consiguiente desnudas y descubiertas sus carnes (...) ». En el edicto prohibía bajo pena de excomunión y severas multas ir en la procesión de la ciudad de Pamplona

«(...) con disciplinas de sangre, barras, espadas, cadenas ni cosas semejantes, permitiendo tan solamente como permitimos disciplinas en seco y sin efusión de sangre, y la penitencia de llevar al hombro alguna cruz o andar con los brazos extendidos o en otra forma decente y edificadora de los fieles, con tal que anden vestidos y con las carnes cubiertas $(. ..){ }^{48}$.

De todas formas lo que más lamentaba el obispo es que muchos de estos flagelantes y portadores de cadenas, exageraban sus mortificaciones, más por afán de exhibicionismo que por un sincero espíritu de penitencia.

Las cortapisas puestas a esta práctica, tanto por la autoridad civil como por parte de la jerarquía eclesiástica no parece que tuvieran al principio mucho eco en el pueblo. En las cuentas de la cofradía de la Vera Cruz de Desojo, se observa todavía en los gastos de Jueves Santo de 1774 cómo se hizo uso de polvos para los disciplinantes. La erradicación de la flagelación pública pues, parece que fue lenta puesto que las reales cédulas contra ella se vuelven a repetir en 1777 y 1792 .

\section{Otros actos de culto}

Las cofradías de la Vera Cruz no sólo celebraban la Semana Santa, sino también otras festividades a lo largo del afio. En primer lugar destacan las cruces de

46 Pedro de Calatayud, Misiones y sermones del P. Pedro de Calatayud, maestro de Teología y misionero apostólico de la Compañia de Jesús, de la provincia de Castilla. Arte y método con que las establece..., Madrid, Imp. de Benito Cano, 1796, vol. I, p. 282.

47 V. DE LA FUENTE, Historia eclesiástica de España, Madrid, 1875, vol. VI, p. 101.

48 AMP, Libro 3." de la Cofradia de la Vera Cruz. 
mayo y de setiembre. Las dos fiestas eran la Invención de la Santa Cruz, el tres de mayo y la Exaltación el catorce de setiembre. En ambos momentos se juntaban a rezar las primeras vísperas, y, en el día, se solian hacer procesiones hasta alguna basílica fuera del pueblo, propia o no de la cofradía, misa solemne y segundas vísperas. En este sentido los cofrades de Puente la Reina peregrinaban a su basílica y el día de Reyes al Convento del Crucifijo ${ }^{49}$. Los de Tudela iban el tres de mayo con la efigie de santa Elena, con el cabildo de la colegiata, hasta una ermita propia de la cofradía, cerca del Ebro. Sobre ella existía la tradición de que el río Ebro, bajando crecido a la altura de la basílica, se paró al llegar a ella ${ }^{50}$. También hacian procesión a su ermita los de Miranda de $\mathrm{Arga}^{51}$, los de Egüés a su basílica ${ }^{52}$, los de Mañeru a la suya ${ }^{53}$, y los de Elorz a la ermita de san Bartolome ${ }^{54}$. Los de Marcilla procesionaban al Calvario ${ }^{55}$. En esos días, particularmente si el lugar donde acudían estaba lejos, la cofradía daba a los hermanos una refacción. En Mañeru se gastaban por ejemplo hacia 1770 catorce cántaros de vino.

También los cofrades tenían la oportunidad de participar comunitariamente en la eucaristía varios días al año, según las reglas de cada cofradía. La de Muruzábal celebraba una misa todos los viernes de cuaresma ${ }^{56}$, en Villava se cantaba en esos días el miserere ${ }^{57}$, en Lerín había misa todos los viernes del affo $^{58}$ en la basílica que la cofradía tenía a las afueras del pueblo, y los domingos de cuaresma; también en Sansol se venía celebrando hasta hace poco tiempo la misa para los cofrades todos los domingos de cuaresma, al igual que en otros muchos lugares. Asimismo se celebraban las tres pascuas del año, el segundo día de Pascua, Corpus Christi y la Ascensión ${ }^{59}$. En Los Arcos habia misa de cofradía todos los segundos domingos de cada mes ${ }^{60}$.

\footnotetext{
${ }^{49}$ AHN, Consejos, leg. 7096, fol. 45r.

50 AHN, Consejos, leg. 7096, fol. 94v.

51 AHN, Consejos, leg. 7096, fol. $131 \mathrm{v}$.

52 AHN, Consejos, leg. 7096, fol. 232v.

53 AHN, Consejos, leg. 7096, fol. 257r.-v.

54 ADP, C/. 650, n. ${ }^{\circ} 3$.

5s AHN, Consejos, leg. 7096, fol. 135r.

56 AHN, Consejos, leg. 7096, fol. 42r.

57 AHN, Consejos, leg. 7096, fol. 68r.

${ }^{58}$ Esto mismo se observa también en las reglas de 1572 de la Vera Cruz de Artajona (ADP, C/. $\left.667, n^{\circ} 22\right)$.

s9 Libro de la cofradia de la Vera Cruz de Sansol, fol. 4. Las constituciones, copiadas en 1880, son un traslado de las aprobadas en 1598 por el arcediano de Vizcaya y provisor del obispado de Calahorra y la Calzada por el obispo D. Pedro Manso.

60 AHN, Consejos, leg. 7096, fol. 270v.
}

Actas del I Congreso de Historia de la Iglesia y el Mundo Hispánico Hispania Sacra, 52 (2000) 
Las cofradías de la Vera Cruz tomaban parte también en cuerpo de hermandad, en las procesiones generales de los pueblos, como nos consta el caso de Lumbier en los días del Corpus o de la Asunción de Ntra. Sra. ${ }^{61}$. También en Torres del Río asistían a la procesión del Corpus ${ }^{62}$.

En tiempos de sequí, excesiva lluvia u otras adversidades climatológicas o de otro tipo (pestes, epidemias agrícolas), se solían organizar procesiones públicas de rogativa en las que participaban todas las cofradias de una misma localidad. Cómo no, también las de la Vera Cruz participaban en ellas. En algunas ocasiones, incluso, llega a haber disturbios por cuestiones de precedencia como ocurrió por ejemplo en Falces, según nos cuentan las actas de un proceso tramitado en el tribunal eclesiástico de Pamplona en 1731 con motivo de unas rogativas organizadas por esa villa para pedir lluvia en un tiempo de sequía. La cofradía de la Vera Cruz y el Santísimo Sacramento de Falces pusieron una queja criminal contra Julián Armendáriz, José de Lana y otros vecinos, porque el estandarte de la Vera Cruz precede a todos los demás, por ser la más antigua y por estar compuesta de las personas de mayor distinción de la villa. Cuentan las actas del proceso que, al regreso de la procesión de rogativa que se había hecho a la basílica de la Virgen de las Arcas, aquéllos individuos pretendieron repetidas veces que el estandarte de la cofradía del Rosario precediera al de la Vera Cruz. El cabildo parroquial de Falces determinó que la procesión volviera de la baślica al pueblo sin pendones para evitar mayores disturbios ${ }^{63}$.

En 1564 con motivo de una peste que asolaba Viana, la cofradía de la Vera Cruz de la localidad hizo una procesión hasta la ermita de Ntra. Sra. de Cuevas para implorar el favor de la Virgen ${ }^{64}$.

Es probable que algunas veces en estas procesiones de rogativas organizadas con motivo de alguna calamidad, hacia los santuarios o basílicas a las que tuviera devoción la población, los hermanos de la Vera Cruz practicaran la flagelación comunitaria para mover a compasión a Dios en orden al cese de tal calamidad. Estas prácticas debían ser frecuentes en otros lugares de España, particularmente en la archidiócesis de Toledo ${ }^{65}$. A este respecto cabe destacar la aventura que Don Quijote de la Mancha tuvo con los disciplinantes, seguramen-

\footnotetext{
6) AHN, Consejos, leg. 7096, fol. 168v.

62 AHN, Consejos, leg. 7096, fol. $272 \mathrm{r}$

$63 \mathrm{ADP}, \mathrm{Cl} / 1847, \mathrm{n}^{\circ} 6$.

64 J. C. Labeaga Mendiola, Contribución al Atlas etnográfico de Vasconia, coord. M. Amor Beguiristáin, p. 681 .

65 J. R. GONZÁLEZ ROMERO, «La sangre y la fe: disciplinantes y penitentes en las cofradias manchegas (siglos XVI-XVIII)", en Religiosidad Popular en Espara: Actas del Simposium (I), $1-4-I X-$ 1997, San Lorenzo del Escorial: Estudios Superiores del Escorial, 1997, p. 615.
} 
te miembros de una cofradía de la Soledad ${ }^{66}$. Algo de esto es lo que debió suceder en Lerín, según se desprende de la ampliación de las constituciones de la cofradía en 1568. En esa villa algunos cofrades se juntaban y se estimulaban unos a otros para aplicarse las disciplinas en un momento y lugar no establecidos por las ordenanzas. No se especifica el motivo por que lo hacían, pero podría ser que para obtener algún bien del cielo que por ese medio esperarían conseguir. La cláusula afiadida en 1568 manda que ningín hermano por sí solo o con otros salga en procesión de disciplina, al tiempo que concede a la junta de la cofradía (prior, mayordomo y conjunto de los cofrades) la facultad de determinar cuándo se puede hacer procesión y flagelación pública ${ }^{67}$. Como se ve, esta constitución deja abierta la posibilidad de marchar en cortejo de rogativas, si la necesidad asf́ lo requiere, disciplinándose. No tenemos más constancia documental de que en el Reino de Navarra se actuara de esta forma frente a cualquier tipo de calamidad. La multa, un ducado, era cuantiosa para aquellos hermanos que se azotaran públicamente sin que lo determinase la junta de la cofradía. De todas formas se dejaba total libertad a los que quisieran hacer penitencia en privado ${ }^{68}$, que, según la ortodoxia de la Iglesia, era algo saludable y servía para merecer delante de Dios.

Otros actos de culto que organizaban las cofradías de la Vera Cruz eran los sermones de Descendimiento o de Soledad, la tarde del Viernes Santo. Los orfgenes de este sermón son muy antiguos y se podrían remontar a los dramas litúrgicos medievales, que se introducían en la liturgia a modo de tropos en el ciclo de navidad o en el triduo pascual. No obstante parece que la función del Descendimiento cobrará gran auge en España en el siglo XVII, y alcanza en el XVIII su mayor esplendor ${ }^{69}$. Para la realización de esta función se requería un cristo articulado, como lo tenían por ejemplo en Lumbier, aunque aquí, al parecer, no era organizado este acto por la cofradía de la Vera $\mathrm{Cruz}^{70}$. Se trata en definitiva de una representación teatral en la que un predicador se dirige, con tono más emotivo y patético cada vez, a los oyentes y a la Virgen y las santas mujeres al pie de la cruz, y luego se procede poco a poco a descender de la cruz

66 Quijote, I, cap. LII.

67 ADP, Cl.9, n. 17.

68 «(...) y si alguno hiçiere la dicha disçiplina por penitençia o otra deboción, la haga a solas y sin çitar a otro que le acompane; y el tal que así la hiçiere la dicha penitencia baya sin capillo, sin cordón y sin escudo de la pasión, porque yendo de esta manera no sea conoscido por tal cofrade.n

69 Sobre los origenes medievales de esta función puede verse J. SANCHEz HERRERO, «Las celebraciones del Descendimiento y Santo Entierro en el contexto teológico y popular de los siglos XII al XVI", en Actas del Tercer encuentro para el Estudio Cofradiero: En torno al Santo Sepulcro, Zamora, 1995, pp. 91-109.

${ }^{70}$ AHN, Consejos, leg. 7096, fol. 171v. 
al cristo articulado, siguiendo los pasos que se hubieran seguido en el momento real cuando Cristo fue bajado para llevarlo al sepulcro. Mientras el sacerdote va predicando, los fieles reviven el descendimiento como si realmente hubieran estado presentes en el Calvario. En primer lugar se arrima a la cruz una escalera, luego se quita a Cristo la corona de espinas, luego los clavos, luego se desclava la imagen y se le desciende de la cruz, hasta colocarla delante de la Soledad de María y por último sería puesto en el sepulcro. En cada uno de estos momentos, el predicador iría dramáticamente ambientando el evento ${ }^{71}$.

Para este acto, así como para otros cultos de Semana Santa se solia traer un predicador extraordinario, como consta a lo largo del siglo XVIII en la cofradía de Torres del Río ${ }^{72}$. En este pueblo tenía lugar el sermón del descendimiento el Viernes Santo por la mañana ${ }^{73}$. Había también funciones del descendimiento organizadas por la cofradía de la Vera Cruz en Muruzábal ${ }^{74}$, en el convento de san Francisco de Tafalla ${ }^{75}$, en Murillo el Fruto ${ }^{76}$ y en Los Arcos ${ }^{77}$. En Goizueta se encargaba de él la cofradía de la Soledad o de los Dolores de María ${ }^{78}$.

También en algunas cofradías, por ejemplo en Sansol, se ordena diariamente la oración vocal de cada miembro de cinco padrenuestros y avemarías «(...) en nombre de penitencia a honor y reverencia de las Cinco Llagas de Jesucristo y cuando muriese algún cofrade lo recen doblado (...)».

\section{b) Actividades caritativas}

\section{Ayuda a los enfermos y pobres}

Cuando algún hermano de la cofradía estuviera enfermo de muerte, el prior y mayordomos de la misma designaban a aquellos cofrades que fuesen a hacer turnos de vela, día y noche. Las constituciones de la Vera Cruz de Villafranca preveían una multa de un real y la expulsión de aquel que pertinazmente deso-

\footnotetext{
7 No he encontrado todavia impreso ni manuscrito ninguno de estos sermones en Navarra. Sobre La Rioja puede verse F. LABARGa García, «Devoción a la pasión, predicación y cofradias: la función del Descendimiento en La Riojay, en Religiosidad Popular en España: Actas del Simposium (l). 1-4LX-1997, San Lorenzo del Escorial: Estudios Superiores del Escorial, 1997, pp. 673-691

72 ADP, Archivos Parroguiales, caj. 238, n. 3, libro de cuentas de la cofradía de la Vera Cruz de Torres del Rio que comienza en 1690 y termina en 1765 , passim.

$73 \mathrm{AHN}$, Consejos, leg. 7096, fol. 272r.

74 AHN, Consejos, leg. 7096, fol. 42r.

15 AHN, Consejos, leg. 7096, fol. 130r.

76 AHN, Consejos, leg. 7096, fol. 145r.

7 AHN, Consejos, leg. 7096, fol. 270v.

78 AHN, Consejos, leg. 7096, fol. 67r.
}

Actas del I Congreso de Historia de la Iglesia y el Mundo Hispánico Hispania Sacra, 52 (2000) 
bedeciera en esto ${ }^{79}$. De todos modos al comportarse con diligencia en este aspecto, los cofrades sanos se aseguraban así que, cuando ellos cayeran enfermos, los demás actuarían igualmente con ellos. Las constituciones de la cofradía de Sada de Sangüesa mandan que, después de que algún hermano haya recibido el viático, nombren los mayordomos permanentemente, día y noche, de tres en tres horas, a dos cofrades para que le acompañen y ayuden a bien morir ${ }^{80}$.

Cuando algún hermano estaba tan enfermo que había que administrarle el viático, todos los demás acompañaban al Santísimo con sus velas encendidas hasta la casa del enfermo. Esto era algo general en todas las cofradías, no sólo en las que ahora nos ocupan.

En el caso de que un miembro llegara a ser tan pobre que no pudiera mantenerse, las constituciones de la cofradía de Villafranca, redactadas hacia 1575, mandaban que «(...) el prior y mayordomos sean tenidos de hazer pidir cada domingo limosna para sustentación del tal hermano...como para pobre enbergonçante». Lo mismo se estilaba en otros lugares, como en Sansol, en que el prior y mayordomos nombrarían dos personas honradas de la cofradía en orden a que pidiesen limosna secretamente para el hermano pobre, como para pobre vergonzante.

\section{Ayuda a los difuntos}

En la mentalidad de los navarros de los siglos modernos era importante el asegurarse la vida más allá de la muerte. Por ello eran importantes los sufragios por el descanso del alma. En muchos aspectos las cofradías rurales de la Vera Cruz se constituían en este sentido en una «sociedad de socorros mutuos») en la que cada hermano se financiaba un número digno de sufragios después de su muerte, que acelerarfan su entrada en la gloria. Para ello pagaban a la cofradía en dinero o en especie durante el tiempo de su vida, y con estos recursos aquélla les garantizaba la celebración de las misas de sufragio. En la cofradía de la Vera Cruz de Elorz cada hermano contribuia al entrar, en concepto de entrático medio robo de trigo, un cuartal para «(...) los gastos y misas de la dicha cofradía, y el otro quartal por la finança y missas que se huuieren de decir por el tal confrade quando muriere (...)). Luego, cada afio, contribuiría con la limosna de un cuartal de trigo ${ }^{81}$.

\footnotetext{
${ }^{79} \mathrm{ADP}, \mathrm{C} / 63, \mathrm{n} .{ }^{\circ} 10$.

${ }^{80} \mathrm{ADP}, \mathrm{C} / .1280, \mathrm{n}^{\circ} 28$

81 ADP, C/.650, n. ${ }^{\circ} 3$.
}

Actas del I Congreso de Historia de la Iglesia y el Mundo Hispánico

Hispania Sacra, $52(2000)$ 
El número de sufragios que había que rezar por los cofrades difuntos varía según las constituciones de cada cofradía. En Villafranca o en Sansol es una misa de terno solemne por cada miembro, en Elorz tres misas, y en Enériz el número simbólico de 33 , los años que Jesucristo vivió en la tierra ${ }^{82}$.

El día de Ánimas, o en la semana de Todos los Santos, como se solía hacer en Sansol, había un aniversario general, esto es una misa de terno celebrada por las almas de todos los cofrades muertos durante el año, incluyendo un responso por cada uno de ellos.

También contribuian estas instituciones a arroparse mutuamente en un momento tan importante como es la hora de la muerte. De este modo todo el mundo se aseguraba el morir acompanado y, lo que es más importante, las oraciones de los demás por su alma. En todos los estatutos de cofradías, y por inclusión también en los de la Vera Cruz, se preveía que todos los miembros acompanfaran en el entierro de cualquier hermano difunto. A él asistían generalmente con las velas encendidas, y en Elorz incluso, con las túnicas de la cofradía y las cabezas descubiertas. Los porteros, mufiidores o cursores eran los encargados de avisar por cada lugar el fallecimiento de cualquier hermano. Todos los cofrades vivos estaban obligados a ir a él. Había multas serias por dejar de asistir, como en el caso de la cofradía de Villafranca en que se estipulaba el pago de un cuarterón de cera para la institución ${ }^{83}$.

Para gozar del acompañamiento y los sufragios de las cofradías, en muchas de sus constituciones, se preveía el ingreso de un hermano después de muerto, pagando normalmente el doble que en vida ${ }^{84}$.

En muchas de estas cofradías, por ejemplo en las de Artajona ${ }^{85}$, Sansol o en la de Torres del Río ${ }^{86}$, se disponía que cuando muriese cualquier miembro, se llevase a su casa el árbol de la cruz de la cofradía, junto con la parroquial, y luego a su entierro. Cualquier habitante de Torres del Río en los siglos XVII y XVIII, aunque no fuera cofrade, podía solicitar el acompafiamiento del árbol de la cruz de la cofradía, pagando doce reales de vellón. A los hermanos se les hacía el servicio gratuitamente.

\footnotetext{
82 ADP, Consejos, leg. 7096, fol. $41 \mathrm{r}$.

$83 \mathrm{ADP}, \mathrm{C} / .63, \mathrm{n}^{\circ} 10$.

34 Esto se observa, por ejemplo, en la cofradia de la Vera Cruz de Artajona, donde el que ingresara después de muerto, debía pagar 24 reales, una cantilad bastante superior al robo de trigo y seis reales de entrático que se pagaba en vida (ADP, C/. 667, n..$^{\circ} 22$ ).

83 ADP, C/. 667, n. 22.

86 Hoy todavía en los funerales de los cofrades de la Vera Cruz de Torres del Río, se sigue llevando a la casa del difunto un árbol de la cruz y el pendón de la cofradía, cuando este va a ser transportado a la iglesia para hacerle el funeral de cuerpo presente. La cruz y el pendón presiden la procesión funeraria hasta la iglesia, los actos litúrgicos y luego la conducción hacia el cementerio y el entierro.
} 
Los gastos del entierro corrían normalmente por cuenta de los familiares de cada difunto, excepto si éste era pobre. En ese caso lo enterraban de limosna, con la cera de la cofradía ${ }^{87}$.

\section{c) Actividades sociales}

\section{Contribución a la paz vecinal}

Mucho debieron contribuir estas instituciones a suavizar tensiones entre las gentes de los pueblos y por tanto a conseguir la paz vecinal, máxime teniendo en cuenta que la práctica totalidad de las personas de los núcleos rurales era miembro de ellas. En todas las constituciones de estos organismos se recogen cláusulas en este sentido, que debieron ser efectivas. Uno de los días en que los hermanos se tenían que reconciliar unos con los otros era el de Jueves Santo antes de salir la procesión. En ese día los cofrades se reunían para escuchar, antes de la procesión, el sermón de mandato, en torno al mandamiento nuevo del evangelio de san $\mathrm{Juan}^{88}$. El programa pastoral de estas cofradías era perfecto. Como hemos dicho antes, para el día de Jueves Santo los cofrades debían estar confesados, reconciliados con Dios, y comulgados. Ahora era el momento de ponerse en paz con el prójimo, a lo que ayudaba sin duda un buen sermón de mandato. Después de la reconciliación, todos hermanados, participaban en una cena, más o menos frugal, en recuerdo de la que tuvo Jesús con sus discípulos ${ }^{89}$. En Torres del Río solían comer lechugas en ensalada, frutos secos (higos pasos, avellanas), diversos dulces, miel, fruta (camuesas), y vino ${ }^{90}$ : no comían carne. Ya podían salir en la procesión para hacer penitencia y merecer ante Dios, y, una vez comidos, afrontar los rigores de la disciplina sin desmayar por la pérdida de sangre. También tenían oportunidad para reconciliarse en los capítulos generales de cada cofradía, por la cruz de mayo o por la de setiembre. Si uno, a instancias del prior y mayordomos, se negaba pertinazmente a ponerse en paz con quien estuviera enemistado, sería expulsado, según se estilaba en todas estas asociaciones.

\footnotetext{
${ }^{87}$ Así se procedia en Sada de Sangüesa o en Sansol.

88 "Os doy un mandamiento nuevo: que os améis los unos a los otros. Que, como yo os he amado, así os améis también vosotros los unos a los otros. En esto conocerán todos que sois discípulos míos: si os tenéis amor los unos a los otros» (Jn XIII, 34-35).

89 Así interpretan la cena en las reglas de la Vera Cruz de Sansol.

90 ADP, Archivos Parroquiales, caj. 238, n. ${ }^{\circ} 3$, Libro de cuentas de la Cofradía de la Vera Cruz de Torres del Río, passim. De la misma forma se procedía en las demás cofradías de este tipo.
}

Actas del I Congreso de Historia de la Iglesia y el Mundo Hispánico Hispania Sacra, 52 (2000) 


\section{Extirpación de la blasfemia}

En algunas reglas de estas instituciones (Villafranca, Artajona) he encontrado capítulos referentes a votar a Dios, o tomar su Nombre en vano, jurando por él sin ser requerido por la autoridad competente. La sanción en este sentido era grande, pues «(...) allende de la pena de la ley y si conforme a ella fuere castigado por jurar, caiga y incurra en penna de dos libras de cera para la dicha confradía, e además de la dicha pena, éste aya destar subiecto a la correctión del dicho prior e castigo que le diere e penitencia que le impusiere (...) ${ }^{91}$. Además si un hermano oyese a otro blasfemar o jurar contra Dios, la Virgen o algún santo, tenía que denunciarlo a la cofradía. Parece, por estas constituciones, que el votar a Dios y jurar por Él estaba muy extendido en la sociedad de la época ${ }^{92}$. No hemos podido comprobar hasta qué punto serían efectivas estas disposiciones. De todas formas en 1731, cuando comienza sus misiones el P. Calatayud, este vicio parece que sigue extendido entre la gente del pueblo.

\section{Asistencia a los condenados a muerte}

Muy interesante era el aspecto de asistencia social que ofrecian estas instituciones, destacando en este sentido entre todas la de Pamplona. Ésta ayudaba a bien morir y acompaniaba en los últimos momentos a los condenados a muerte, a los que proporcionaba alimentos; y luego, una vez que eran ajusticiados, les hacía el funeral y entierro de limosna en el convento pamplonés del Carmen Calzado (a partir de 1628 en el de san Francisco), donde poseía sepulturas para este efecto ${ }^{93}$. Esta facultad la poseía la cofradía de manera auténticamente monopolística ${ }^{94}$. Igualmente la cofradía de la Vera Cruz de Estella presenta este carácter ${ }^{95}$.

\footnotetext{
$91 \mathrm{ADP}, \mathrm{C} / .63, \mathrm{n}^{\circ} 10$.

92. Conocemos la creación de cofradías específicas en esta época contra el mal hablar. En 1567, para combatir esto, el obispo pamplonés Diego Ramírez Sedeño de Fuenleal encargó a los dominicos de Sangilesa que instituyeran la cofradía del Santo Nombre de Jesús, extensible también a otros pueblos vecinos (Cfr. J. GoÑ GazTAMBIDE, Historia de los obispos de Pamplona, v. IV (Pamplona, 1985), p. 207).

93 M. NÚNEZ DE CEPEDA, op. cit., pp. 292-293.

94 Cfr. ADP, Cl. 306, n. 18.

95 J. Goñi Gaztambide, Historia Eclesiástica de Estella, v. II (Pamplona, 1990), pp.104-106.
} 


\section{Su organización interna (cargos directivos, juntas)}

a) Cargos directivos.

1. Prior o abad. Es la máxima autoridad de la cofradía. Puede haber dos priores, uno seglar y otro eclesiástico. Raras veces el cargo suele recaer únicamente en un sacerdote como sucede en Sada de Sangliesa ${ }^{96}$. De todas formas los sacerdotes tienen gran importancia en la designación de los nuevos responsables de la cofradía, pues, como disponen las constituciones de la del valle de Elorz, el prior y mayordomos salientes elegian a los nuevos "con asistençia de los saçerdotes confrades della, para que sepan llegar hombres de buena vida y exemplo (...) $)^{97}$.

2. Mayordomos. Su número varía según las cofradías. Normalmente suele haber dos. En el caso de Sansol o de Artajona hay uno, en el de Cascante seis ${ }^{98}$, y en el de Pamplona ocho, dos por cada parroquia de la ciudad. Dirigían la cofradía junto con el prior y se encargaban de la administración de los bienes de la cofradía. Tenían un amplio poder ejecutivo del que a veces abusaban, imponiendo arbitrariamente multas por incumplimiento de las constituciones ${ }^{99}$. A veces la tarea de mayordomo resultaba ciertamente gravosa porque tenían que sufragar de su propio peculio gastos en comidas o de otra índole. A veces la mayordomía se perpetuaba durante años en miembros de una misma familia y, si tenían gastos, «sus casas iban en detrimento», como sucedía en el caso de la Vera Cruz de Miranda de Arga, en que además los mayordomos tenían a su cargo la luminaria de la capilla del Cristo ${ }^{100}$.

3. Diputados. Su número también era variable, pudiendo haber hasta diez, como en el caso de Sansol. En la cofradía de Villafranca dispusieron que hubiese tres. Su función era aconsejar al prior y mayordomos en el gobierno de la cofradía.

4. Porteros, cursores o muñidores. Solía haber dos. Se encargaban de trasladar a los demás hermanos lo que mandaran el prior o mayordomos, de avisarlos con una campanilla a las juntas de cofradía, o de la defunción de algún cofrade.

\footnotetext{
\% ADP, C/. 1280, n. 28 .

$97 \mathrm{ADP}, \mathrm{C} / 650, \mathrm{n} .{ }^{\circ} 3$.

98 J. I. FERNÁNDEZ MARCo SJ, op. cit., p. 127.

99 Esto es lo que dice Martín de Ororbia menor, de 33 affos, nuncio y pregonero de la villa de Artajona en 1615, que Tomás de Olleta, mayordomo que fue de la cofradía de la Vera Cruz, le entregó una lista contra más de cien cofrades para que ejecutase la pena cobrando a cada uno medio real porque faltaron a las primeras vísperas de la santa Cruz y al día siguiente a misa y vísperas. (ADP, $\mathrm{C} / .667, \mathrm{n}^{\circ}{ }^{22}$, $\sin$ fol.).

${ }_{100} \mathrm{AHN}$, Consejos, leg. 7096, fol. 132r.
}

Actas del I Congreso de Historia de la Iglesia y el Mundo Hispánico Hispania Sacra, $S 2$ (2000) 
Los responsables de la cofradía debían ser personas ejemplares en su comportamiento para los demás. La duración de todos estos cargos era anual y no podía recaer en las mismas personas dos años seguidos. Los salientes elegian a los nuevos, los cuales les «tomaban residencia» del estado de las cuentas y el actuar durante su mandato. Cuando un hermano era elegido prior o mayordomo, no podía renunciar, so pena de ser expulsado de la institución. La nueva elección de cargos se solía hacer normalmente en las juntas de las cofradías el día de la Cruz de mayo.

\section{b) Las juntas}

El conjunto de los hermanos se reunía tres veces al afio normalmente: Jueves santo, antes de salir la procesión, y los días de la Cruz de mayo y setiembre. En estas dos últimas fechas se trataban asuntos de la cofradía y había comidas de hermandad. Lo que se deliberara en esas juntas era secreto, como se recoge en muchas constituciones. Todos los hermanos debjan observar un comportamiento correcto y sólo tenían la voz cuando el prior se la diese, para lo cual les entregaba un crucifijo. Sólo podía hablar en la reunión aquel que tenía el crucifijo y los demás escuchaban ${ }^{101}$. En estas juntas se votaba además la admisión de los nuevos cofrades que quisieran entrar. Si habia algún asunto urgente, el prior podía congregar excepcionalmente a los hermanos en junta extraordinaria para que emitieran su voto.

\footnotetext{
101 Esto se observa ya en el siglo XVI (por ejemplo, en las constituciones de la cofradía de Villafranca $-\mathrm{ADP}, \mathrm{C} / .63, \mathrm{n}^{\circ} 10$ ), y en momentos posteriores casi hasta nuestros dias en las cofradias que han perdurado, como en la de Sansol.
}

Actas del 1 Congreso de Historia de la Iglesia y el Mundo Hispánico Hispania Sacra, 52 (2000) 